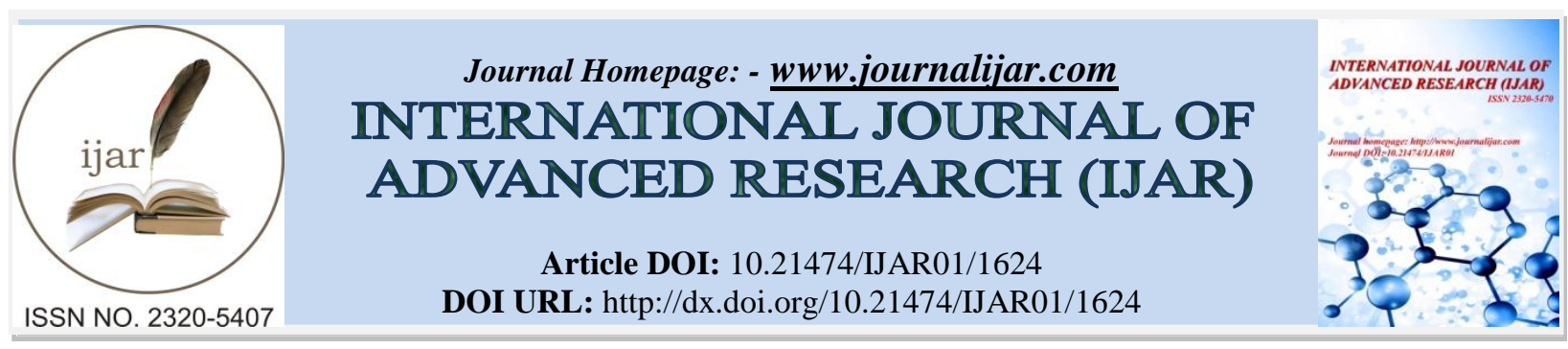

RESEARCH ARTICLE

\title{
MICROBIAL TREATMENT OF TEXTILE INDUSTRY EFFLUENT: AN ECOFRIENDLY RECOURSE.
}

Farida P. Minocheherhomji.

Associate-Professor, Microbiology Department, B. P. Baria Science Institute, NAVSARI - 396445, Gujarat, India.

\section{Manuscript Info}

Manuscript History

Received: 12 July 2016

Final Accepted: 19 August 2016

Published: September 2016

Key words:-

Enzymes, Environmental pollution, Microbial treatment, Synthetic dyes, Textile effluent

\begin{abstract}
The basic aesthetic interest of human beings is of them resorting to colored materials. This has led to the exploration of dyes for coloring different materials which are used in day to day life. Dyeing and printing of clothes is a concept predating to as far as history can take us. This was a door to door unorganized approach using few colors produced from natural sources. But after the development of synthetic dyes, textile processing has developed to a large industrial scale in last six to eight decades. Over and above textiles, dyes have been used by leather, paper, plastic and even food industries which also lend their hand in contribution of environmental pollution. The use of these dyes has led to severe environmental, terrestrial and aquatic pollution as the large volume of effluent released by these units contained unfixed dyes and strongly acidic or basic chemicals. Physical and chemical effluent treatment, is a costly process, that has been made compulsory by almost all government agencies around the globe. This also resorts to different chemical based coagulating agents, which ultimately increase the output cost of the final product Microbial treatment of this effluent has proved to be a successful, eco-friendly and the ultimate approach. This review article has been aimed to compile different work in this aspect for the better understanding of the subject.
\end{abstract}

Copy Right, IJAR, 2016,. All rights reserved.

\section{Introduction:-}

Clothing is one of the basic requirements of human beings. Colors add aesthetic value to the clothes. Hence, coloring of textiles has its roots reaching to thousands of years back. The older methods of coloration of textile were on an unorganized and small scale using a few dyes incorporated from natural sources. But with the advent of synthetic dyes based on different chemical groups like Azo, Anthraquinone, Quinaphthalene, Methine, Napthalimide, Napthaquinone and Nitro, textile processing industry has witnessed a tremendous growth at industrial level around the globe. These units are the largest consumer of fresh water using different classes of dyes and chemicals for varying qualities of fabrics. This leads to generation of high volume of contaminated water creating potentially hazardous environmental pollution problem around the globe. This contamination of textile effluent includes different chemicals of either highly acidic or basic $\mathrm{pH}$, coupled with unexhausted dyes possessing a very high tinctorial value.

In a textile processing unit, after the completion of dyeing and printing process, a certain amount of dyes remain unexhausted in the dye-bath, or some dyes taken up by the fabric are again washed off during washing, rinsing and final finishing operations. This depends on the type of the fabric being dyed, class of dyes used and the dyeing 
technique being followed. Reactive dyes in particular are highly soluble in water, and so have a tendency to prevail in the dye-bath, remaining unexhausted. Use of exhausting agents like Common Salt $(\mathrm{NaCl})$ or Glauber Salt $\left(\mathrm{Na}_{2} \mathrm{SO}_{4}\right)$ improves the exhaustion, but still a certain percentage of dyes remain unexhausted in the dye-bath. In case of disperse dyes used for the coloration of polyester fabrics, if the dyes used are above their saturation limit as specified by the dye manufacturer, then these dyes are again vomited /expelled out by the fabric on rinsing, or on application of heat for thermosetting of the polyester fiber. Such unexhausted or washed off dyes are commonly referred to as 'Spent Dyes'. These spent dyes are washed off with other chemicals used during the process in the effluent. Degradation or decolorisation of these spent dyes is necessary, and it is successfully carried out by different treatment procedures

Removal of dyes from textile effluent is very important as even a small concentration of dyes is visible even in large water bodies due to their high tinctorial power, ${ }^{1,2}$. This creates haziness in the water body, leading to reduction in the penetration of light in water, thus hampering the growth of aquatic plants due to drastic reduction of natural process of photosynthesis. Many dyes are also toxic, mutagenic and carcinogenic in nature ${ }^{3,4,5,6}$.

During last six to eight decades, synthetic dyes have been mainly used in dyeing and printing of fabrics. Hence, treatment of textile effluent has become more difficult as synthetic dyes possess complex aromatic structures making them extremely stable and simultaneously difficult to biodegrade ${ }^{7}$. Azo dyes have accounted for more than half of the total available disperse dyes. The normal methods of effluent treatment employ both physical and chemical processes. The physical processes are sedimentation, aeration, straining, filtering / screening, adsorption followed by chlorination, ozonation, neutralization and treatment with chemical coagulants / flocculants to precipitate the contaminants as sludge. Further advanced processes include electrocoagulation, denitration, membrane filtration / separation, photo catalytic reduction, advanced oxidation, nutrients removal by struvite crystallization and nano technology. Disposal of this sludge is also difficult and is to be done under strict supervision by government agencies and pollution control boards; a highly uneconomical method, leading to many industries flouting norms and disposing untreated waste water in to the water bodies; a environmental hazard.

\section{Microbial Degradation of Textile Effluent:-}

Microbial degradation is the most environment friendly way of degradation and decolorisation of the spent dyes present in the effluent. This is accomplished in three ways by using all three types of microorganisms. The three main degradation methods are:

1. Fungal Biodegradation

2. Bacterial Biodegradation

3. Biodegradation using Yeast

\section{Fungal Biodegradation:-}

Studies have been focused by different researchers on the microbial degradation of textile effluent using organisms like Aspergillus niger, which have the capacity to remove the dyes from the effluent by biosorption. Biosorption is due to the action of the functional groups of the fungal organism on to the chemical structure of the dyes ${ }^{8}$. Similarly, yeast Candida tropicalis has a good bioaccumulation capability of reactive dyes like blue, black and red colors?

A wide spectrum of organisms like bacteria, filamentous White rot fungi, yeasts and algae have the capability of decolorizing textile dyes by anaerobic, aerobic and sequential anaerobic and aerobic processes ${ }^{\mathbf{1 0}}$. Researchers have also concluded that anaerobic systems were more effective in degrading the spent color present in the effluent compared to the aerobic process. But the main clinch observed was the formation of carcinogenic amines due to reductive cleavage of the azo bond in the chemical structure of the dye by the action of bacterial azoreductase ${ }^{11}$.

Unfixed Azo dyes present in the effluent are removed by the cleavage of their azo bond specifically by enzymes such as Azo reductases. Whereas enzymes like lignin peroxidase, phenoxidase, manganese peroxidase and laccase, which are produced by White Rot fungi ${ }^{12}$, have a potentially better capability of aerobically degrading the aromatic chemical structure of the dyes ${ }^{13,14}$. Azo groups like triphenylmethane, phthalocyanine and heterocyclic dyes and other chemicals present in the effluent are easily decolorized by the action of liginolytic enzymes of White rot fungi ${ }^{15,16}$.

Fungi decolorization of spent Acid dyes used during the coloration of protein fibers like wool, alpaca and mohair and silk, and Reactive dyes used for coloring cotton and viscose, can be effectively carried out in the presence of 
Penicillium species, Aspergillus niger and Plouritus ostreatus at lower concentrations. Decolorisation of acid dyes and reactive dyes was optimal at $\mathrm{pH} 4$ and 5 respectively as the White rot fungi had an optimal growth at $\mathrm{Ph} 4-5^{7}$.

Another organism, Trametes hirsute produced enzyme laccase which was able to effectively degrade a variety of dyes of chemical groups like anthraquinone, azo, indigoid and triarylmethane. The rate of decolorisation was also dependent on the substituents on the phenolic ring of the dye structure. Immobilization of the Trametes hirsute laccase on Alumina enhanced the thermal stability of the laccase enzyme, and also its tolerance potential against some enzyme inhibitors like halides, inorganic / metallic chelating agents, generally copper based, and dye auxiliaries present in the effluent ${ }^{17}$. Decolorization of dyes by Trametes hirsute has been mainly attributed to extracellular laccase activity.

Laccases enzymes like benzenediol oxygen oxireductase are able to degrade a wide range of spent dyes due to its broad substrate specificity related to the electron donor. Laccases have been observed to speed up the Hydrogen atom removal from the hydroxyl group of the aromatic amine of the dye molecule by one electron abstraction, to form free radicals which are capable of undergoing further depolymerisation, repolymerisation, demethylation and quinine formation. The broad substrate specificity of laccases is also due to the action of redox mediators secreted by lignolytic fungi ${ }^{17}$.

Enzyme Laccase has been employed in the treatment of effluent released from pulp and paper mills containing a higher percentage of chlorolignins or phenolic compounds. This enzyme Laccase is able to convert the highly toxic phenolic compounds to lesser toxic components by degradation or polymerization reactions and / or cross-coupling of pollutant phenols with naturally occurring phenols. Different processes using enzyme laccase as well as immobilized laccase have been developed for the treatment of phenolic effluents and polycylic aromatic hydrocarbons ${ }^{17,18}$.

Physical factors like time, temperature, $\mathrm{pH}$ and presence of Carbon / Nitrogen sources play a decisive role on the decolorization efficiency of the fungus.

\section{Effect of Time, Temperature and pH on the Degradation Efficiency:-}

A study carried out on Direct dye: Solar Brilliant Red 80 showed that the decolorization efficiency of bacterium Schizophyllum commune IBL-06 was maximum on the $7^{\text {th }}$ day at $30{ }^{\circ} \mathrm{C}$ and incubation $\mathrm{pH} 4.5$, reaching almost up to $85 \%$. It was also noticed that the rate of decolorization was on an increase up to 7 days, which later stabilized with no further increase. This decolorisation efficiency of Schizophyllum commune IBL-06 was due to it secreting three ligniolytic enzymes: lignin peroxidase, manganese peroxidase and laccase, which play a decisive role in the decolorisation process. It was also noticed that the production of enzyme: lignin peroxidase was highest, followed sequentially by manganese peroxidase and laccase. The superb ability of White rot fungi to completely or partially decolorize different spent dyes present in the textile effluent is directly due to its efficiency in production of ligninolytic enzymes in the culture medium, and was also on the spent dye concentration in the effluent. Schizophyllum commune belongs to different White rot fungal species like Trametes versicolor, Phanerochaete chrysosporium, Irpex lacteus, Pleurotus ostreatus and Bjerkandera species are able to efficiently decolorise / degrade spent dyes of different classes and chemical groups present in the textile effluent ${ }^{19}$.

\section{Effect of Carbon and Nitrogen Sources:-}

Carbon and Nitrogen are necessary for the synthesis and growth of different ligninolytic enzymes by the fungus in the aqua medium ${ }^{19,20}$. Feeding of a combination of cheap Carbon supplements like glucose, maltose, sucrose, fructose and starch; and Nitrogen supplements like Ammonium nitrate $\left(\mathrm{NH}_{4} \mathrm{NO}_{3}\right)$, Ammonium sulphate, Ammonium dihydrogen phosphate and urea provide a boost to the development of enzymes in the medium, ultimately increasing its decolorisation efficiency at optimal time, temperature and $\mathrm{pH}^{19}$.

The combination of maltose and Ammonium sulphate, followed by glucose and Ammonium dihydrogen phosphate is best suitable in increasing the dye degradation potential of the secreted enzymes. The degradation potential of Tinea versicolor was observed to increase with the increased feed concentration of Ammonium nitrate ${ }^{21}$. This was due to the maximum growth of enzyme lignin peroxidase followed by manganese peroxidase and laccase. It was also observed that the White rot fungus strain Schizophyllum commune IBL-06 had a good potential of it being used in the treatment of spent textile dyes effluent due to it possessing a potentially better ligninolytic enzyme system ${ }^{19}$. 


\section{Bacterial Biodegradation:-}

Bacteria used in the biodegradation of dyes are Bacillus subtilis, Escherichia coli and some Pseudomonas species by aerobic-anaerobic reaction. Six strains of Aeromonas hydrophilla have been successful in the degradation of azo dyes. These bacterial agents work to stimulate coagulation / flocculation of the spent dyes.

\section{Spent Dye Removal by Bacterial Flocculants:-}

Dye degradation potential of bioflocculants produced by isolates of bacterial species like Bacillus subtilis, Exiguobacterium acetylicum, Klebsiella terrigena, Staphylococcus aureus, Pseudomonas pseudoalcaligenes, and Pseudomonas plecoglossicida have been successfully incorporated for effluent spent dye degradation. Bioflocculant producing bacteria have been successfully isolated from the activated sludge.

Bioflocculants produced by all the bacterial isolates were able to decolourize the textile industrial effluent with an extremely high degradation rate of 80 to $97 \%$ for different dyes by their causing aggregation of dye molecules and cells by bridging and charge neutralisation ${ }^{22}$. Bridging is the extension of the flocculant from the dye molecule surface into the solution for a distance exceeding which the interparticle repulsion occurs. Thus the biopolymer adsorbs to other particles to form flocs. A particle-polymer-particle complex is formed in which the polymer acts as a bridge. An effective bioflocculant molecule should contain chemical groups able to interact with active sites on the surface of the colloidal particle. These bioflocculants worked efficiently at neutral $\mathrm{pH} 7.0$, whereas the degradation decreased slightly in case of some dyes in both slightly acidic $\mathrm{pH} \mathrm{6.0,} \mathrm{and} \mathrm{alkaline} \mathrm{pH}$ 8.0. The rate of dye degradation drastically reduced at $\mathrm{pH} 10.0$. The best working temperature for these flocculants was observed to be in the range of $33-40{ }^{\circ} \mathrm{C}^{22}$.

Thus bacterial bioflocculants have been able to provide a more cleaner and eco-friendly approach to the treatment of textile effluent by supplementing or fully replacing the existing chemical flocculant process as they themselves are fully biodegradable.

\section{Yeast Biodegradation:-}

A limited amount of study has been done using different species of yeast as agents for biodegradation of textile dyes. A strain of Candida zeylanoides has been successfully tested to degrade some azo dyes of simple chemical structure in liquid aerated bath culture. The amount of dye degradation varied from $43 \%$ to as high as $90 \%$ after 7 days $^{23}$. Remaxol Black B dye has been successfully decolorized using yeast Kluyveromyces marxianus. Maximum decolorisation to the extent of $98 \%$ was observed at $37{ }^{\circ} \mathrm{C}^{24}$. Bacillus subtilis has also been used to degrade the structure of some azo dyes ${ }^{25}$.

\section{Conclusion:-}

Treatment of dye effluent is a difficult task because it is a complex process involving different factors like temperature, $\mathrm{pH}$, salt concentration and presence of different heterogeneous chemicals of opposite chemical composition to each other. Conventional effluent treatment requires large inputs of costly chemical agents as flocculants coupled with high inputs of energy and man-power. This makes the operation cumbersome, as well as increasing the cost of production, a factor detrimental to the basic survival of the textile industry which in the current times is precariously balancing itself on knife-edge for its ultimate survival.

Microbial treatment involving fungal, bacterial and yeast as agents for degradation of dyes is a economical and the best alternative, as it is devoid of heavy inputs of energy, manpower and chemicals. The process generally works at Room Temperature, so there is no dissipation of heat in the surrounding atmosphere; thus playing a pivotal role in lowering the temperature of the environment.

A noticeable draw-back of enzymatic effluent treatment is during the reuse of the treated water in dyeing and printing process. The color tone of the fabrics processed with this recycled water slightly differs from the original. This color difference is measured spectrophotometrically, and the 'Delta- $\mathrm{E}$ ' $(\Delta \mathrm{E}$ or $\delta \mathrm{E}$ ) value, which represents total color difference from batch-to-batch of the dyed fabric is observed to be more than 1, which is unacceptable according to international standards. This is due to the fact that the active enzyme proteins present in the reused water lead to binding of the auxochromes to the dye molecules. It also affects the dyeing process by interfering in the dye fixation caused by the aggregation of dye molecules, thus hampering the dye uptake by the fabric. Research is underway to avoid these problems by deactivation of the enzyme in the treated water before reuse. 


\section{Bibliography:-}

1. Kim HT, Lee Y, Yang J, Lee B, Park CH, Kim S (2004); Decolorization of dye solution by a membrane bioreactor (MBR) using white-rot fungi; Desalination, 168 pp. 287-293.

2. Park CH, Lee M, Lee B, Kim SW, Chase HA, Lee J, Kim S (2006); Biodegradation and biosorption for decolorization of synthetic dyes by Funalia trogi; J. Biochem. Eng. 1-7.

3. Gong R, Ding Y, Mei L, Yang C, Liu H, Sun Y (2005); Utilization of powdered peanut huil as biosorbent for removal of anionic dyes from aqueous solution; Dyes Pigment, 64: 187-192.

4. Nigam P, Armour G, Banat IM, Singh D, Marchant R (2000); Physical removal of textile dyes effluents and solid-state fermentation of dye-adsorbed, agricultural residues; Bioresour. Technol., 72: 219-266.

5. Birhanli A, Oznen M (2005); Evaluation of the toxicity and teratogenity of six commercial textile dyes using the frog embryo teratogenesis assay-xenopus; Drug Chem. Toxicol., 1: 51-65.

6. Degon E, Yesilada E, Ozata L, Yologiu S (2005); Genotoxic testing of four textile dyes in two crosses of Drosophila using wing somatic mutation and recombination test; Drug Chem. Toxicol.

7. Ali NF, El-Mohamedy RSR (2012); Microbial decolorization of textile waste water; Jr of Saudi Chem Soc, 16(2): 117-123.

8. Fu Y, Tiraraghavan Y (2001); Fungal decolorization of dye waste water, a review; Bioresour Technol, 79: 251262.

9. Donmez G (2002); Bioaccumulation of reactive textile dyes by Candida tropicolis growing in molasses medium; Enzyme, 30: 363-366.

10. Asgher M, Kamal S, Iqbal HMN (2012); Improvement of catalytic efficiency, thermo-stability and dye decolorization capability ofPleurotus ostreatus IBL-02 laccase by hydrophobic Sol-Gel entrapment; Chemistry Central Journal, 6 (1): 110.

11. Pearce CI, Lloyd JR, Guthrie JT (2003); The removal of colour from textile wastewater using whole bacterial cells: a review; Dyes and Pigments, 58 (3): 179-196.

12. Fu Y, Viraghavan T (2002); Dye biosorption sites in Aspergillus niger; Bioresour Technol, 82: $139-145$.

13. Atlas RM (1993); Hand Book of Microbiological Media; CRC Press Inc., USA.

14. Iqbal HMN, Asgher M, Bhatti HN (2011); Optimization of physical and nutritional factors for synthesis of lignin degrading enzymes by a novel strain of Trametes versicolor; BioResources, 6 (2): 1273-1287.

15. Tavcar M, Svobodova K, Kuplenk J, Novotny C, Pavko A (2006); Biodegradation of azo dye RO16 in different reactors by immobilized Irpex lacteus; Acta Chimica Slovenica, 53: 338-343.

16. Senthilkumar S, Perumalsamy M, Janarthana Prabhu H (2011); Decolourization Potential of white rot fungi Phanerochaete chrysosporium on Synthetic dye bath effluent containing Amido black 10 B; Journal of Saudi Chemical Society, http://dx.doi.org/10.1016/j.jscs.2011.10.010.

17. Abadulla E, Tzanov T, Costa S, Robra K-H, Cavaco-Paulo A, Gubitz GM (2000); Decolorization and Detoxification of Textile Dyes with a Laccase from Trametes hirsute; Appl Environ Microbiol, 66(8); 33573362.

18. Asgher M, Iqbal HMN, Asad MJ (2012); Kinetic characterization of purified laccase produced from Trametes versicolor IBL-04 in solid state bio-processing of corncobs; BioResources, 7: 1171-1188.

19. Asgher M, Quamar Y, Iqbal HMN (2013); Enhanced decolorization of Solar brilliant red 80 textile dye by indigenous white rot fungus Schizophyllum commune IBL-06; Saudi Jr of Bio Sci, 20(4): 347-352.

20. Selvam K, Swaminathan K, Rasappan K, Rajendran R, Pattabhi S (2006); Decolorization and dechlorination of a pulp and paper industry effluent by Thelephora sp.; Ecology Environment and Conservation, 12: $223-226$.

21. Asgher M, Azim N, Bhatti HN (2009); Decolorization of practical textile industry effluents by white rot fungus Coriolus versicolor IBL-04; Biochemical Engineering Journal, 47(1): 61-65.

22. Buthelezi SP, Olaniran OA, Pillay B (2012); Textile dye removal from waste water effluent using bioflocculants produced by indigenous bacterial isolates; Molecules. 17: 14260-14274.

23. Martins MA, Cardoso MH, Queiroz MJ, Ramalho MT, Campos Am (1999); Biodegradation of azo dyes by the yeast Candida zeylanoides in batch aerated cultures; Chemosphere, 38(11): 2455-2460.

24. Meehan C, Banat IM, McMullan G, Nigam P, Smyth F, Marchant R (2000); Decolorization of Remazol BlackB using a thermotolerant yeast, Kluyveromyces marxianus IMB3; Environ Int, 26(1-2): 75-79.

25. Zissi W, Lyberatus G, Pavlou S (1997); Biodegradation of paminoazobenzene by Bacillus subtilis under aerobic conditions; J Ind Microbiol Biot, 19: 49-55. 